\title{
Development of a cost controlling system for an investment and construction project
}

\author{
Maria Bovsunovskaya* \\ Moscow State University of Civil Engineering, Yaroslavskoe shosse, 26, Moscow, 129337, Russia
}

\begin{abstract}
The study is devoted to substantiating the need to develop a cost controlling system in order to improve the efficiency of investors, developers, customers, general contractors, as well as representatives of the banking system who are directly involved in the implementation of investment and construction projects. The paper summarizes the innovations of the Ministry of Construction, Housing and Utilities of the Russian Federation in the field of determining the cost of construction at the stages of the life cycle of an investment and construction project, and suggests their adaptation to the activities of commercial customers. The factors of the rise in the cost of construction in the modern conditions of the investment and construction sphere are systematized, including topical issues of the rise in cost due to the increase in prices of building materials. The main risks arising from the implementation of the project associated with an increase in cost are highlighted. As the results of the study, stages of construction cost control with a description of their content and a system of cost controlling of an investment and construction project are proposed.
\end{abstract}

\section{Introduction}

The investment and construction sector of Russia is influenced by the geopolitical situation on the world stage and the economic consequences of the COVID-19 pandemic. This leads to a reduction in the resource potential of construction organizations, the emergence of difficulties in the sale of construction products, which leads to the risk of an increase in the cost of investment and construction projects.

In this regard, in the practical activities of the investment and construction sector, cost controlling is of particular relevance, which makes it possible to analyze current and possible costs, potential and actual cost deviations, as well as their consequences and expected results from the investor, customer and (or) other participants during the project implementation period.

In many ways, cost controlling is associated with the process of managing the project cost: determining the cost of construction, budgeting and cost control. It details the stages of cost control and management decisions made on its basis. At the same time, it is typical for controlling not only to record financial results and provide leadership with the necessary information to justify management decisions, but to focus on long-term cash flows, based on cost values, and assess the results of construction in terms of invested funds.

${ }^{*}$ Corresponding author: BovsunovskayaMP@mgsu.ru 


\section{Materials and methods}

Nowadays, significant changes are taking place in the field of pricing in construction at the state level: the pricing system is aimed at reliable determination of value at all stages of the implementation of an investment and construction project, for which the Ministry of Construction, Housing and Utilities of the Russian Federation proposes a number of new methods that consistently describe the process of value formation. Methods have been developed that are posted on the official websites of the Ministry of Construction, Housing and Utilities of the Russian Federation. These documents are mandatory in terms of financing construction projects with the involvement of funds from the budgetary system of the Russian Federation. Depending on the stage of the project, various types of cost are distinguished: the planned (marginal) at the pre-project stage, the estimated at the stage of architectural and construction design, the initial maximum contract price and the final price (estimate) of the contract at the stage of passing the competitive procedures, as well as the actual cost of building the facility, formed in the course of work (Fig. 1).

The interrelation of various types of construction costs ensures the logic and consistency of cost calculations in the process of project implementation, and also enables the Customer to use the current calculation standards. The system for determining the cost of construction, developed for government orders, is also adaptable for commercial construction. In this case, there will be no clear link to the established estimated standards. Commercial rates or market prices may be used as agreed by the parties.

Despite the existence of a methodological basis for calculating the cost, the question arises of its control in terms of deviations when performing work under a contract (or an agreement - in the case of commercial financing) $[1,2]$. Due to the duration of the project, the cost of construction may change (increase) for a number of reasons, which will have negative consequences for the state customer (violation of the terms of the state contract); commercial customer (decrease in project efficiency); contractors (increase in the cost of work, the possibility of non-payment for work).

The increase in construction costs may affect the interests of the banking system. At the moment, the volume of housing, which is being built using the escrow account mechanism, has sharply increased. At the end of January, it exceeded $52 \%$ of the total volume of housing under construction [3]. Before receiving project financing, the developer substantiates the economic indicators of his project to the bank, thereby actually recording all costs. And if there is some change in value in the future, all risks associated with an increase in the cost of construction are assigned to the construction company. Closer to the end of construction, when the limit of credit funds is exhausted, and the object is not yet completed, it will be forced to use its own working capital and its profits to complete the construction. Otherwise, it will violate the terms of the lending agreement with the bank, and it is almost impossible to increase the volume of lending to the bank for the already started projects. This jeopardizes contractual obligations, can lead to bankruptcy of construction companies and the appearance of new defrauded equity holders. 


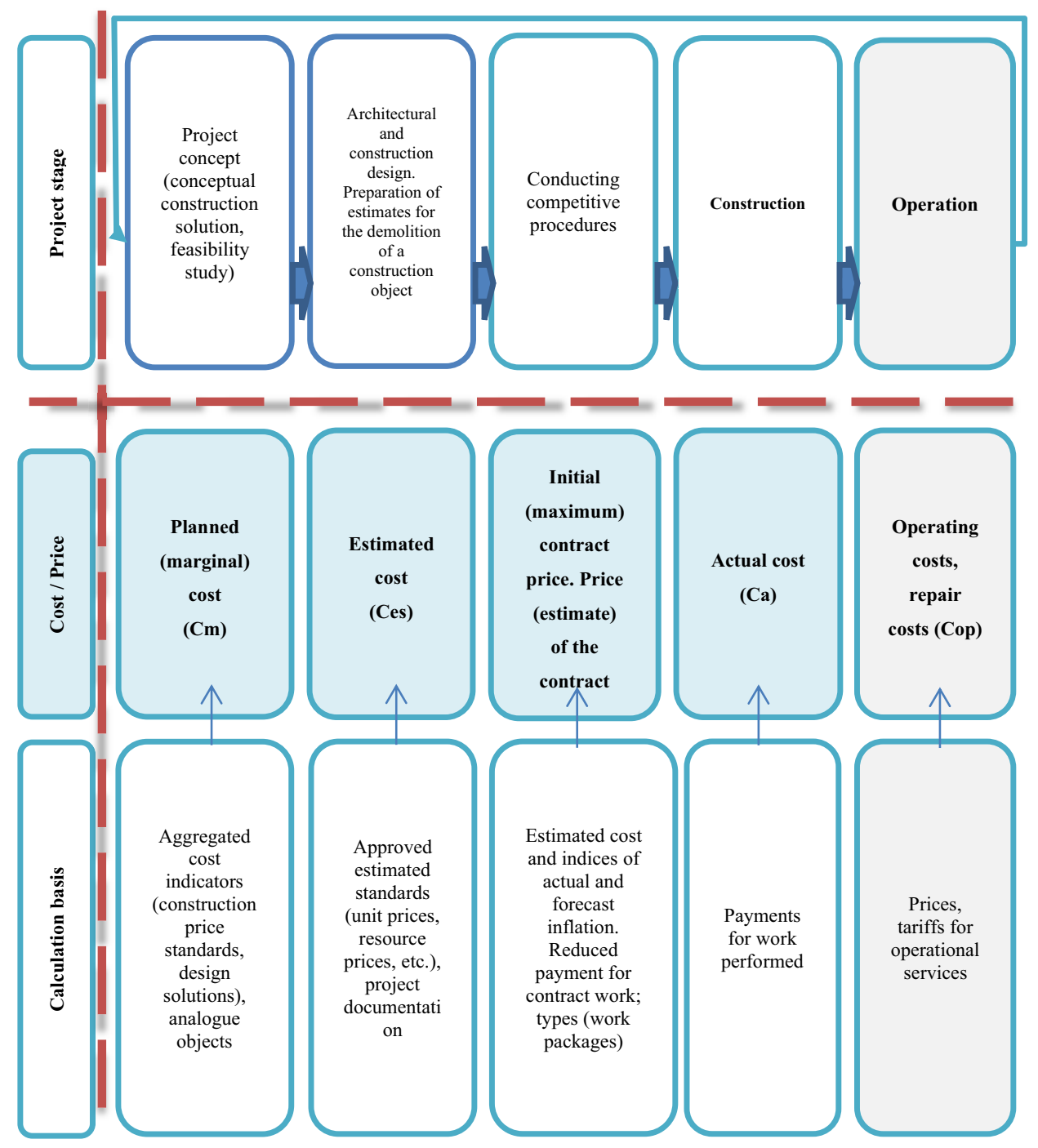

Fig. 1. The process of forming the cost of construction at various stages of the life cycle of an investment and construction project.

On the one hand, the cost of building an object may change due to unskilled management of the construction progress, unfair overpricing, loss of building materials due to improper storage, and so on. All these reasons are in the developer's area of competence, and he is responsible for raising the cost of the project. On the other hand, the price of construction can be influenced by objective factors that do not directly depend on its participants - for example, inflation, changes in the exchange rate, force majeure, a sharp change in climatic conditions, and much more. Let's highlight the objective and subjective factors of the rise in the cost of construction (table 1).

If subjective factors can be leveled within the organization, then objective factors are difficult to predict in advance. Thus, the rapid rise in metal prices, which was observed in the Russian Federation in the period from the end of 2020 to the beginning of 2021, in various positions is estimated from 60 to $100 \%$. In this regard, an increase in the cost of 
construction of objects is predicted by market experts by at least 7-10\% [3]. At the same time, in some cases, the contract price, due to the current legislation, cannot be increased, even under such significant circumstances as an increase in the purchase price of metal. Although it is quite obvious that an increase in the cost of metal, depending on the object, leads to a significant increase in the cost of construction. We assume that the next stage of price growth will be an increase in prices for metal products: electrical and fire cabinets, cables, heating and water supply pipes, elevators, and so on, the main consumers of which are usually the construction and housing sectors. This will again lead to an increase in the cost of construction and a situation in which the construction company will be forced to work at a loss under a government contract. And this can lead to non-performance of the contract and bankruptcy of the company.

Table 1. Factors of increasing the cost of construction.

\begin{tabular}{cc}
\hline Objective factors & Subjective factors \\
\hline $\begin{array}{c}\text { Abnormal climatic and weather conditions, natural } \\
\text { disasters. }\end{array}$ & $\begin{array}{c}\text { Errors in the design process: redundant space- } \\
\text { planning solutions; selection of ineffective } \\
\text { design solutions; irrational object placement. }\end{array}$ \\
$\begin{array}{c}\text { Sharp inflationary growth. Significant change in } \\
\text { national currency rates. A sharp change in the cost } \\
\text { of third-party services used in the construction } \\
\text { process }\end{array}$ & $\begin{array}{c}\text { Unqualified management of the construction } \\
\text { progress, inaccurate determination of the cost, } \\
\text { errors associated with the construction } \\
\text { organization project }\end{array}$ \\
$\begin{array}{c}\text { Changes in construction legislation. Changes in } \\
\text { the tax system. }\end{array}$ & $\begin{array}{c}\text { Loss of material resources due to incorrect } \\
\text { storage conditions, etc. }\end{array}$ \\
$\begin{array}{c}\text { Innovative technologies in construction or } \\
\text { production of materials and equipment }\end{array}$ & Low innovation activity of construction \\
companies
\end{tabular}

In this regard, it is necessary to ensure control over the cost of the project and make quick decisions on its basis, because controlling is not a control oriented to the past, but the management of the current analysis processes and the operation of planned and actual indicators, which are aimed at predicting positive and negative deviations in the project and minimizing their results $[4,5,6,7]$.

\section{Research results}

The goal of the cost controlling of an investment and construction project can be defined as ensuring the timely completion of an investment and construction project within the planned budget without losing the quality of the object through the design and cost management of the object in the implementation process, leveling the risks of cost overruns and controlling the cost of performed work.

Due to ineffective cost controlling, the following risks of project implementation may arise:

1. Increase in the cost of construction, including the specific cost indicator (for example, square meters);

2. The emergence of accounts payable for additional work, violation of contractual obligations.

3. Decrease in the investment attractiveness of the project; decrease in the profitability of the project.

All of the above risks create the risk of untimely commissioning of the facility, delay in implementation, and long-term construction. To level these risks, a system of cost controlling is proposed, which at all stages of the project marks the control points for determining the cost and identifying current deviations $[8,9,10,11]$. 


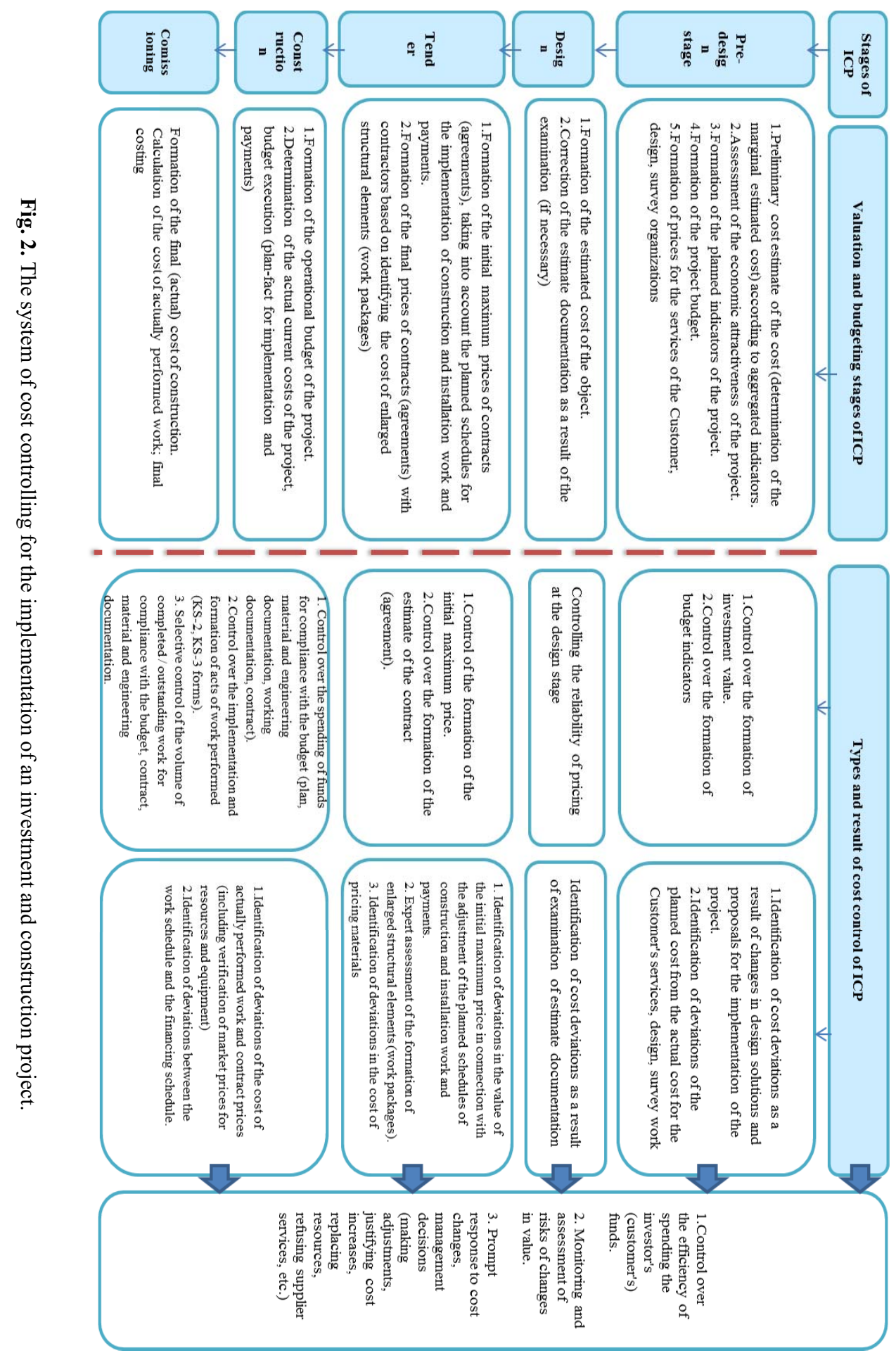


The proposed system clearly demonstrates the sequence of cost controlling activities at all stages of the project. It is important to emphasize that there is a difference between the implementation of projects with the attraction of private and public investment. Thus, a check for the reliability of determining the estimated cost, carried out when passing the examination of project documentation for a state order, is not carried out in the case of a commercial order. However, it can be replaced, for example, by an internal audit of the estimated cost in the Customer's organization.

Thus, the implementation of value controlling is based on a system of control measures at all stages of an investment and construction project:

- $\quad$ substantiation of expenses for design and survey work;

- calculation of the economic attractiveness of the project;

- $\quad$ substantiation of design solutions and substantiation of the efficiency of their changes (if necessary);

- formation of estimate documentation, contract (agreed) prices;

- performance of work: compliance of the actual cost with the schedule, plan, budget.

The most controversial moment in the process of cost controlling is the issue of changing the cost and replacing material resources during the construction process [12]. So, the estimates and reports of the contractor should be analyzed for correctness of drawing up and compliance with real market prices. In order to detect unlawful overpricing in the estimates and reports of the contractor, financial documents - invoices, receipts for payment, transfer of funds, etc. - can be examined. Such verification often reveals the misuse of funds. Acceptance by the state customer for payment of works and materials that do not correspond to those actually performed indicates the inappropriate use of budget funds.

The objective difficulty lies in the fact that when using forecast inflation indices in determining the price of a contract (agreement) and determining the estimate of a contract (agreement), it is very difficult to predict fluctuations in market prices for price-forming material resources. Therefore, for the objects being designed at the moment, it is necessary to quickly recalculate the price indices for such materials as metal (both for state and commercial orders). But for objects already being implemented (the estimate documentation for which has already passed the examination or construction contracts have been concluded with a firm contract price), the issue of increasing the cost becomes more relevant, since the actual rise in the cost of construction cannot be avoided.

The following conceptual measures can be proposed at the state level to ensure effective cost controlling of investment and construction projects:

1. Timely updating of state prices for pricing materials in accordance with market conditions.

2. Possibility of indexing prices (one-time) in the contract (in the agreement) in the event of an objective increase in the cost of the price-generating resources.

3. Possibility to provide a reserve of funds for unforeseen expenses on pricing materials in the amount of not 2 (3) \%, but, for example, $8-10 \%$.

4. Developing the industry and logistics of building materials in the domestic market.

Thus, the permanent analysis of the control results, the generation of reports on deviations and potential risks of the project, the identification of management decisions make cost controlling an essential element of the investment and construction project management system. 


\section{Conclusion}

A cost controlling system allows participants to be better prepared for the overall project flow and to be able to control cost throughout the design and construction process. Cost controlling is focused on the economical use of available resources, ensuring the profitability of activities and preventing the risk of increasing value. The process of cost controlling is the most important tool that allows one to quickly and immediately control the cost of a project and make decisions regarding identified deviations, thereby reducing all possible risks. The development of cost controlling of projects has great potential for application in the practical activities of companies in the investment and construction sector, including in the development of electronic information programs.

\section{References}

1. Kontrolling proekta: uchebnoe posobie / T. N. Gladchenko, I. V. Kostenok. - Doneck: DonGUU, 2016. - 212s.

2. Uvarova S.S., Belyaeva S.V., Panenkov A.A., Belyanceva O.M. Realizaciya stoimostnogo audita v stroitel'stve usloviyah cifrovizacii // Ekonomika v investicionnostroitel'nom komplekse i ZHKKH, Voronezh, 2019. 2(17), S. 73-79.

3. Anton Glushkov. Takoj rost cen na metall stroitel'naya otrasl' perevarit' ne v sostoyanii. Agentstvo novostej «Stroitel'nyj biznes», interv'yu s prezidentom NOSTROJ Antonom Glushkovym. URL: http://ancb.ru/publication/read/10789 Data obrashcheniya 16.02.2021

4. SHeshukova T.G. K evolyucii ponyatiya «Kontrolling»/ SHeshukova T.G., Harina A.A. // Sbornik nauchnyh statej po buhgalterskomu uchetu, ekonomicheskomu analizu i auditu, posvyashchennyh yubileyu zasluzhennogo professora NNGU im. N.I. Lobachevskogo, doktora ekonomicheskih nauk E.A. Mizikovskogo Pod redakciej I.E. Mizikovskogo, E.S. Druzhilovskoj, A.A. Bazhenova. Nizhnij Novgorod, 2018. - S. 352357.

5. Gusev M.M. Differenciaciya podhodov i funkcij kontrollinga// Vestnik Altajskoj akademii ekonomiki i prava. Barnaul, 2011. 3(21), S.65-66.

6. Kontrolling : uchebnik / A. M. Karminskij, S. G. Fal'ko, A. A. ZHevaga, N. YU. Ivanova ; pod red. A. M. Karminskogo, S. G. Fal'ko. - 3-e izd., dorab. - Moskva : FORUM : INFRA-M, 2021. - 336 s. - (Vysshee obrazovanie: Bakalavriat). - ISBN 978-5-8199-0825-9. - Tekst : elektronnyj. - URL: https://znanium.com/catalog/product/1165262 (data obrashcheniya: 22.02.2021). Rezhim dostupa: po podpiske.

7. Bondareva N.G., Ushakov V.A. Kontroling kak instrument povysheniya effektivnosti upravleniya predpriyatiem // Novaya nauka: strategii i vektory razvitiya. Ufa, 2016, 6-1 (88). - S. 58-60.

8. Bovsunovskaya M.P., Sajdakova D.D. Stoimostnoj kontrolling kak instrument snizheniya riskov investicionno-stroitel'nogo proekta// Vestnik Altajskoj akademii ekonomiki i prava, №11, 2020, s. 420-424.

9. Bovsunovskaya M.P. Document support of cost management in underground construction projects// Procedure Engineering 165 (2016) $960 \quad-964$. https://doi.org/10.1016/j.proeng.2016.11.806/.

10. Didkovskaya O.V., Mamayeva O.A., Ilyina M.V. Development of cost engineering system in construction// Procedure Engineering 153 (2016) 131 - 135. 
11. Malahov V.I. Vvedenie v sistemnyj investicionno-stroitel'nyj inzhiniring (bazovyj kurs). -3-e izdanie - Moskva: Izdatel'stvo «DPK Press», 2019, - ISBN: 978-5-91976-126-6.

12. Bovsunovskaya M.P., Tarasov P.YA. Feasibility study of the use of PVC roofing membranes in the Russian market// Ekonomika i predprinimatel'stvo, №5 (118), 2020, s. 1102-1104. 